\title{
Anti-cancer, Anti-invasiveness \& Anti-metastasis of Green Engineered Bioorganic-Capped Silver Nanoparticles Fabricated from Juniperus chinensis Extract and Comparison to Cisplatin in Lung Cancer Cells (A549): In Vitro Assessment of Cellular and Molecular Pathways
}

Hassan Noorbazargan ( $\sim$ h.noorbazargan@gmail.com )

Shahid Beheshti University of Medical Sciences School of Medicine https://orcid.org/0000-0003-18890139

Ainaz Mashayekhi

Islamic Azad University

Nazanin Khayam

Islamic Azad University

Mohammad Naghizadeh Islamic Azad University

Amir Mirzaie Islamic Azad University

Aghigh dolatabadi Islamic Azad University

Pooria moulavi Islamic Azad University

Sobhan amintehrani

Islamic Azad University

Mahsa kavousi

Islamic Azad University

Original article

Keywords: Juniperus chinensis, Human lung cancer cells, Green synthesized AgNPs, apoptosis, metastasis

Posted Date: October 9th, 2020 
DOI: https://doi.org/10.21203/rs.3.rs-88253/v1

License: (c) (1) This work is licensed under a Creative Commons Attribution 4.0 International License. Read Full License

Version of Record: A version of this preprint was published at AMB Express on April 26th, 2021. See the published version at https://doi.org/10.1186/s13568-021-01216-6. 


\section{Abstract}

The current study reveals anti-cancer properties of bio-functionalized silver nanoparticle (AgNPs) fabricated by Juniperus chinensis leaf extracts due to it's easy, low cost, biological activity, eco-friendly and lower side effects. The characteristics of AgNPs were determined by scanning electron microscopy [1], transmission electron microscopy (TEM), UV-visible spectroscopy, Fourier transform infrared (FTIR) spectroscopy, X-ray diffraction, Dynamic light scattering (DLS), Zeta potential and X-ray spectroscopy (EDX). Further, this study highlights the cellular and molecular mechanisms of AgNPs involves in antiproliferative and apoptotic effect on human lung cancer cells (A549) and compared to commercial drug cisplatin by various biological methods such as MTT, flow cytometery analysis, gene expression patterns, migration and invasion inhibition, ROS and caspase production and cell staining. The size of AgNPs fabricated in this study was 12.96 with spherical shape and negative zeta potential. Up-regulation of capase 3,9 and p53, Annexin V-FITC/PI, DAPI staining, ROS production indicated remarkable apoptotic effect of AgNPs than cisplatin. Also down-regulation of MMP2/MMP9 scratch and matrigel assays revealed anti-metastatic properties of AgNPs.cell cycle analysis and down regulation of cyclin D1 showed cancer cell cessation in the G0/G1 phase. Overall results in current experiment revealed AgNPs synthetized by biogreen method anti-metastasis and anti-proliferation effect on lung cancer cells comparison to cicplatin drug and also had lower side effect on normal cell line.

\section{Introduction}

Silver nanoparticles are one of the preferable nanomaterials that progressively becoming a section of human daily lives.[2]. Recently AgNPs thanks to their marvelous and unparalleled nano-related features, have been applied extensively in different fields of science especially in biomedical field and have also been studied for their antimicrobial effects[1], wound healing[3] and anticancer [4] activity. A variety of procurement techniques are utilized for the synthesis of silver nanoparticles, among these methods, the usage of plant extracts are more attractive due to the availability of more biological entities, eco-friendly procedures, cost-effective, abundantly renewable, and safe nature for human therapeutic use [5]. A huge data evidenced numerous phytochemicals compounds such as flavones, lignins, and terpenes present in different parts of plants have been identified that are triggered in anti-microbial and anticancer activities of phyto-synthesized AgNPs[6].

AgNPs are being utilized for treating different types of cancerous cells due to their especial and particular extraordinary biomedical applications (anti-cancer, anti-bacterial, anti-viral and anti-angiogenic properties) and their surface specific features[7]. Various studies indicated the apoptotic effect of silver nanoparticles on colon cancer HT29 cell line29[8], as well as the cytotoxic effects and anticancer activity of phyto-synthesized silver nanoparticles on breast cancer MCF-7 cell line [9]and HeLa cervical cancer cells[10]. Further studies on mouse model with tumor revealed that the AgNPs can significantly expand the survival time in comparison with tumor controls and consequently show satisfactory antitumor and anti-angeogenic effect[11]. The biological results acquired from researches showed anti-cancerous and anti-proliferative activity of biologically synthesized silver nanoparticle lung cancer A549 cells and non- 
cytotoxicity were observed due to its ability to arrest the cell cycle at G1 phase[12]. The evidence obtained from one study confirms that bio-sythesized AgNPs using the Juniperus chinensis leaf showed the potent anticancer effect on the human adenocarcinoma gastric (AGS) cell lines[13].

Cisplatin is a chemotherapy medication used to treat a number of cancers such as bladder cancer, head and neck cancer, esophageal cancer, lung cancer, mesothelioma, brain tumors and neuroblastoma. Its serious side effects include numbness, trouble walking, allergic reactions, electrolyte problems, and heart diseas. This drug works in part by binding to DNA and inhibiting its replication[14, 15]. Hence, this study was conducted to analyze the anticancer effects of green-synthesize AgNPs using Juniperus polycarpos on A549 (adenocarcinomic human alveolar basal epithelial cells) cell lines, as well as comparison of this synthetic AgNPs with Cisplatin commercial drug.

\section{Methods}

\section{Plant materials and compounds extraction}

The plant leaf of Juniperus polycarpos were obtained from the Plant Bank - Iranian Biological Resource Center. Leaves were dried under direct sunlight for 48 hours and ground to make a fine powder using a stainless blender. The powder was exposed to $500 \mathrm{~mL}$ of $80 \%$ methanol $(\mathrm{MeOH})$ for 12 hours. Then the extract was subsequently filtered and concentrated using a vacuum rotary evaporator at $40{ }^{\circ} \mathrm{C}$ giving semi-solid extracts and were maintained at $4^{\circ} \mathrm{C}$ for applying on cancer cells.

\section{AgNPs phyto-synthesis and characterization}

0.01 molar silver nitrate was weighted, then $40 \mathrm{ml}$ of distilled water and $4 \mathrm{ml}$ of plant extracts were added and shaken vigorously. After one day, Change in colour of the solution to dark brown colour were monitored to determine nanoparticles formation. The preparations were then centrifuged at $13000 \mathrm{rpm}$ for $10 \mathrm{~min}$. Supernatants were discarded and the pellet was washed twice in $10 \mathrm{ml}$ of distilled water to remove any contaminating plant material and centrifuged at $13000 \mathrm{rpm}$ for $15 \mathrm{~min}$ again. At least, the mixture was dried at $37^{\circ} \mathrm{C}$ for $24 \mathrm{~h}$ to come in powder form.

X-ray diffraction (XRD) (PW3710, the Netherlands) with CuKa radiation $(\lambda=0.0260 \mathrm{~nm})$ and Fouriertransform infrared spectroscopy (FTIR technique) were applied for the crystal phase analysis of the AgNPs powders. The synthesis of AgNPs was measured using a UV-1800UV-spectrophotometer (Shimadzu, Japan). The particles size, morphology and distribution were detected using scanning electron microscopy [1] (LEO SEM 1450VP, UK) and transmission electron microscopy [8] (FEl 5022/22 Tecnai G2 20 STwin, CR) and Energy Dispersive Spectroscopy (EDS).

\section{A549 Cells culture}

The human lung cancer A549 cell line was purchased from Iranian Biological Resource Center. The cell lines A549 (ATCC) were cultured at $37^{\circ} \mathrm{C}$ and in a $5 \% \mathrm{CO} 2$ in air atmosphere. All cells tested negative for mycoplasma contamiinations and were markedly cultured in fresh medium (RPMI1640) supplemented 
with $10 \%$ fetal bovine serum (FBS, DENAzist Asia's Co) and 1\% antibiotics (penicillin/streptomycin). The cells $(1 \times 106 \mathrm{cell} / \mathrm{ml})$ were plated in T-25 flasks containing $5 \mathrm{mls}$ of RPMl1640 and grown in a humidified incubator under an atmosphere of $95 \%$ air and $5 \% \mathrm{CO} 2$ at $37^{\circ} \mathrm{C}$ to subconfluence $(90-95 \%)$. The culture medium was replaced every 48 hours. Once the cells reached $90-95 \%$ confluency, the medium was aspirated, and the cells monolayer was washed three times with sterile phosphate buffered saline. The cell monolayer was treated with $1 \mathrm{ml}$ of $0.25 \%(\mathrm{w} / \mathrm{v})$ trypsin-EDTA and incubated briefly at $37^{\circ} \mathrm{C}$ and visualized microscopically to ensure complete cell detachment. Cells were re-suspended in complete growth medium. Cells were also stained with trypan blue $(100 \mu \mathrm{l}$ of cell suspension and $100 \mu \mathrm{l}$ of $0.4 \%$ trypan blue), incubated for 2 minutes at room temperature, and counted using a hemacytometer. The cells were seeded at a density of $1 \times 104$ cells/ well in 96-well microtiter tissue culture plates prior to Vascum album different extracts treatment (33)

\section{Cytotoxicity assay of AgNPs}

The MTT [3-(4,5-dimethylthiazol-2-yl)-2,5-diphenyltetrazolium bromide] assay was performed for assessing cell proliferation activity and cytotoxicity in A549 cells exposed to different concentrations of bio-synthesized AgNPs and cisplatin. Cell viability was determined using the MTT assay 24 hours after incubation. The basis of MTT assay is based on reduction of a tetrazolium component (MTT) into an insoluble formazan product by succinate dehydrogenase activities in mitochondria. The Protocol of MTT assays were conducted according to standard protocols in 96-well plates. A549 cells were seeded in 96well plates with $1 \times 10^{4} \mathrm{cells} /$ well and placed at $37^{\circ} \mathrm{C}$ in a $5 \% \mathrm{CO} 2$ humidified incubator until $60 \%$ confluency.

The complete growth medium was removed and the cells were exposed to serum starvation for $24 \mathrm{~h}$ prior to treatment. Cells cultures were incubated in culture medium for $2 \mathrm{~h}$ alone served as control (untreated cells) for evaluating cell viability. The cells were treated with different doses of $0.78,1.56,3.125,6.25$, $12.5,25,50$ and $100 \mu \mathrm{g} / \mathrm{ml}$ of bio-synthesized AgNPs and 3.125, 6.25, 12.5, 25, 50 and $100 \mu \mathrm{g} / \mathrm{ml}$ of cisplatin, the medium was removed and MTT solution $(100 \mu \mathrm{l})$ were added to each well and incubated for $4 \mathrm{~h}$. The plates were incubated under $95 \%$ atmosphere air and $5 \% \mathrm{CO} 2$ at $37^{\circ} \mathrm{C}$ for $4 \mathrm{~h}$. The MTT solution was removed and $200 \mu \mathrm{l}$ aliquots of DMSO were added to each well to dissolve the formazan crystals followed by incubation for $10 \mathrm{~min}$ at $37^{\circ} \mathrm{C}$. Treatments were performed in triplicates, and optical densities were read at $570 \mathrm{~nm}$ by spectrophotometric method (34). IC50 of AgNPs and cisplatin on A549 cell lines were calculated by the statistical package, Pharm-PCS software.

\section{Evaluation of caspase-3, caspase-9, MMP2 and MMP9 genes expression by Real-time PCR}

RNA extraction from cells was performed using RNX kit (SinaColon Co) according to the manufacturer's instructions. The absorbance of a RNA sample was measured at 260 and $280 \mathrm{~nm}$ by a spectrophotometer for calculating RNA concentration and purity. RNA quality was assessed by gel electrophoresis method on a $1.2 \%$ agarose gel for $1 \mathrm{~h}$ at $100 \mathrm{~V}$. Genomic DNA was removed by RNase-free DNase I (Thermo Scientific). The cDNA synthesis reaction was carried out with Fermentas First Strand 
cDNA Synthesis Kit by RT-PCR method on two $\mu \mathrm{g}$ of the treated RNA, according to the manufacturer's instructions. Agterwards, $1 \mu \mathrm{g}$ of cDNA was applied for assessment of genes expression using specific primers (Table1).

The amplification was carried out in a reaction volume of $25 \mu \mathrm{L}$ including $12.5 \mu \mathrm{l}$ SYBR Green kit

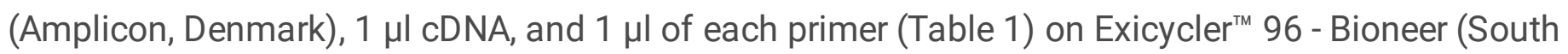
Korea). $\beta$-actin gene has been used as an internal control. In current study, the $2 \Delta \triangle \mathrm{CT}$ method was applied to survey the relative changes in genes expression from real-time quantitative PCR experiments. Data analysis was performed with SPSS statistical analysis software and the results were analyzed by Oneway Analysis of Variance (ANOVA) and Tukey's post hoc-test to determine significant difference between treatments $(P<0.05)$.

Table 1

Primer sequence designated for RT-PCR.

\begin{tabular}{|c|c|}
\hline gene & Primer sequence \\
\hline \multirow[t]{2}{*}{ Casp3 } & Forward: 5'- CATACTCCACAGCACCTGGTTA-3' \\
\hline & Revers: 5'- ACTCAAATTCTGTTGCCACCTT-3' \\
\hline \multirow[t]{2}{*}{ Casp9 } & Forward: 5'-CATATGATCGAGGACATCCAG-3 \\
\hline & Revers: 5'-TTAGTTCGCAGAAACGAAGC-3' \\
\hline \multirow[t]{2}{*}{ MMP2 } & Forward: 5'- F: TTG ACG GTA AGG ACGGAC TC-3' \\
\hline & Revers: 5'-CATACTTCACACGGACCACTTG - 3' \\
\hline \multirow[t]{2}{*}{ MMP9 } & Forward: 5'- GCACGACGTCTTCCAGTACC - 3' \\
\hline & Revers: 5'- CAGGATGTCATAGGTCACGTAGC - 3' \\
\hline \multirow[t]{2}{*}{ b-actin } & Forward: 5'- TCCTCCTGAGCGCAAGTAC-3' \\
\hline & Revers: 5'- CCTGCTTGCTGATCCACATCT-3' \\
\hline \multirow[t]{2}{*}{ Cyclin D1 } & Forward: 5'- CAGATCATCCGCAAACACGC-3' \\
\hline & Revers: 5'- AAGTTGTTGGGGCTCCTCAG-3' \\
\hline \multirow[t]{2}{*}{ P53 } & Forward: 5'- TAACAGTTCCTGCATGGGCGGC -3' \\
\hline & Revers: 5'- AGGACAGGCACAAACACGCACC -3' \\
\hline
\end{tabular}

\section{Apoptosis assay of AgNPs}

The apoptotic toxicity level to the A549 cells was determined by Annexin- V-FITC/propidium iodide staining. According to the manufacturer's instructions, the cells were treated with AgNPs and cisplatin for $24 \mathrm{~h}$. Afterwards, the cells were harvested and centrifuged at $200 \times \mathrm{g}$ and suspended in appropriate 
buffer. Following that, $5 \mu \mathrm{L}$ Annexin-V-FITC labeling and $5 \mu \mathrm{L}$ PI solutions were added to the mixture, which were then incubated for five minutes at $25^{\circ} \mathrm{C}$ and analyzed with flow cytometry (Bd, UK).

\section{Cell cycle analysis}

Cell cycle analysis $5 \times 10^{5}$ A549 cells (cells/mL) were treated with Juniperus polycarpos leaf extract NPs and cisplatin for $30 \mathrm{~min}$. The cells were washed and fixed with $500 \mu \mathrm{L}$ of ice-cold $70 \%$ ethanol and refrigerated for $1 \mathrm{~h}$ prior to staining. The cell pellet was washed and re-suspended in $200 \mu \mathrm{L}$ of Guava Cell Cycle reagent containing $\mathrm{PI}$ and incubated in the dark at room tem perature for 30 min before analysis with Guava® easyCyte. For each step, centrifugation was performed at 5000 rpm for 5 min at room temperature. The data obtained were analyzed using Incyte software.

\section{Scratch wound healing assay}

Cells were seeded in a 6-well culture plate and allowed to reach 70-80\% confluence as a monolayer before they were transfected with siRNAs. The scratch was vertically introduced to the cells in the monolayer using a $10 \mathrm{~mL}$ pipette tip. All the images were captured using OPTIKA B-353-PLi (Italy) microscope system at the respective time points. Each condition was assessed in triplicate and was independently repeated three times.

\section{Matrigel invasion assay}

The cell invasion assay was performed using a 24-well Transwell chamber with a pore size of $8 \mathrm{Im}$ (Corning, ME). The inserts were coated with 100 II Corning Matrigel basement membrane matrix (final concentration of $200 \mathrm{mg} / \mathrm{mL}$, Corning, MA). Twenty-four hours after the transfection, cells $10^{5}$ were trypsinized, and cells in 100 II of serum-free medium were transferred to the upper matrigel chamber and incubated for 18 h. A medium supplemented with $20 \%$ FBS was added to the lower chamber as the chemoattractant. After incubation, the cells that passed through the filter were fixed with Methanol and stained with Giemsa. The number of invaded cells was counted in 5 randomly selected high-power fields under the microscope.

\section{Reactive oxygen species (H2-DCFH-DA) assay}

A549 human lung epithelial adenocarcinoma cells were cultured in minimum essential medium (Hyclone Laboratories, Logan, UT, USA) containing $10 \mu \mathrm{M} \mathrm{H} 2$ - DCFDA in a humidified incubator at $37^{\circ} \mathrm{C}$ for $30 \mathrm{~min}$. Cells were washed twice with warm PBS ( $\mathrm{pH} 7.4)$ and were lysed on lysis buffer (25 mM HEPES [pH 7.4], $100 \mathrm{mM} \mathrm{NaCl}, 1 \mathrm{mM}$ EDTA, $5 \mathrm{mM} \mathrm{MgCl}$, and $0.1 \mathrm{mM}$ DTT containing EDTA-free protease inhibitor cocktail (Roche)). Cells were cultured on coverslips in a 4-well plate. Cells were incubated in DMEM containing $10 \mu \mathrm{M} \mathrm{H} 2-\mathrm{DCFDA}$ at $37^{\circ} \mathrm{C}$ for $30 \mathrm{~min}$. Cells were again washed in PBS and were mounted with VECTASHIELD Mounting Medium for fluorescence with DAPI (Burlingame, CA, USA), and were imaged with a fluorescence microscope.

\section{Caspases activity}


The activity of proteases caspases was detected using the caspase-3 (ab39401) and caspase- 9 (ab65608) kits purchased from Abcam (Cambridge, UK). caspases 3 and 9 recognize the sequence DEVD and LEHD, respectively, and cleave from the labeled substrate p-NA emitting light, which was quantified using a spectrophotometer at $405 \mathrm{~nm}$.

\section{Results}

\section{Characterization of Synthetized Silver Nanoparticles using Juniperus polycarpos}

Change in color of solution with Juniperus polycarpos extract was apperceived after incubation of flask containing $\mathrm{AgNO}_{3}$ at $37^{\circ} \mathrm{C}$ for 24 hours. The color of the extract solution altered from light yellow to dark brown after 24 hours. The alteration in color indicates the accepted synthesis of silver nanoparticles. AgNPs formation also was verified using UV-vis, XRD, FTIR, EDS, SEM and TEM.

\section{UV-vis analysis}

Figure 1 shows the recorded UV-Vis absorption spectra of the synthesized AgNPs by Juniperus polycarpos extract. For UV-vis analysis, the absorption of NPs was detected in $438 \mathrm{~nm}$ wavelength in UV-vis spectrum. Moreover, no additional peaks were noticed in the spectrum, which revealed great purification of synthesized AgNPs .

\section{Characterization of size, morphology and DLS analysis of AgNPs}

SEM and TEM images of AgNPs formed by Juniperus polycarpos indicate the shape, size and morphology of nanoparticles. According to microscopically investigation the green synthesized AgNPs at optimal conditions had maximum average size of 10-50 nm with mean size of $12.96 \mathrm{~nm}$ (Fig. 2).

According to the DLS analysis, the average size of AgNPs was estimated $133.4 \mathrm{~nm}$ and Polydispersity Index (Pdl) value was recorded at 0.254 .

The silver nanoparticles were found to be well, monodispersed from each other and spherical-shaped based on TEM and low pdl value of DLS analysis (Fig. 2c).

\section{XRD, EDX \& Zeta potential}

The XRD patterns of the AgNPs synthesized by Juniperus chinensis extract, four intense XRD peaks were indicated at $2 \theta=38.6,44.4,64.6$, and 77.1 correspond to the (111), (200), (220), and (311) crystallographic planes of facecentered cubic (FCC) structure.

Figure $3 \mathrm{~b}$ shows the EDS analysis of Juniperus polycarpos mediated synthesis of silver nanoparticles. The EDS technique detects a potent signal at $3 \mathrm{keV}$ indicates the presence of elemental silver. EDS 
analysis indicates the elemental analysis of the nanoparticles in which the percentage of silver ions was $99.15 \%$.

In the current study, the fabricated AgNPs had a negative zeta potential of $-9.76 \mathrm{mV}$, indicating higher stability of the bio-functionalized AgNPs (Fig. 3c). The greater negative surface charge potential value indicates that the synthesized AgNPs are high dispersed in the medium with long-term stability [16].

The negative potential value may be due to the reducing and capping substances especially fatty acid in Juniperus chinensis extract also the aggregation of the nanoparticles could be prevented by electrostatic repulsion between negative charge of the nanoparticles $[17,18]$.

\section{Fourier Transform Infrared Spectroscopy (FT-IR) analysis}

The result of FTIR analysis of bio-synthesized AgNp revealed different stretches of bonds at different peaks. The strong and broad peak at $3411.89 \mathrm{~cm}-1$ was related to the stretching vibrations of the $\mathrm{O}-\mathrm{H}$ and $\mathrm{N}-\mathrm{H}$ groups in the extracted. Absorption peaks located at $1619.28 \mathrm{~cm}-1$ and $1385.60 \mathrm{~cm}-1$ are assigned to $\mathrm{C}=\mathrm{C}$ and $\mathrm{C}-\mathrm{H}$ bend alkane groups, respectively. Peak at $1112.81 \mathrm{~cm}-1$ associated with $\mathrm{C}-$ $\mathrm{O}-\mathrm{C}$ stretch ethers, while $621.51 \mathrm{~cm}-1$ represents $=\mathrm{C}-\mathrm{H}$ group in alkenes and aromatic compounds .

Peak at $2925.16 \mathrm{~cm}-1$ corresponds to aliphatic $\mathrm{C}-\mathrm{H}$ group.

\section{Cell Viability and MTT Test Results}

The possible cytotoxicity results of various cisplatin concentrations and AgNPs on HEK293 cells ( obtained from National Cell Bank (NCBI) of Pasteur Institute of Iran), as a normal cell line, and A549, as a cancerous cell line, indicated that plant extract and AgNPs have cytotoxic effects against cancerous cell line while not toxic to the normal cells in lower concentrations(Fig. 5). It was also detected that the maximum cell death was belong to synthesized AgNPs, which was $35 \%$ for the cultured HEK293 cells after 24-hour exposure. This is when cisplatin resulted in 60\% cytotoxicity toward the HEK293 cells. However, the cytotoxicity of AgNPs and the cisplatin against MCF-7 tumor cell line were approximately $60 \%$ and $40 \%$, respectively (at the concentration of $12.5 \mu \mathrm{g} / \mathrm{mL}$ ). As can be seen in Fig. 5 , the toxicity of AgNPs is dose-dependent.

Figure $5 \mathrm{~A}$ and $7 \mathrm{C}$ indicate viability of $\mathrm{A} 549$ and HEK293 cells exposed to $0.78,1.56,3.125,6.25,12.5,25$, 50 and $100 \mu \mathrm{g} / \mathrm{ml}$ of bio-synthesized AgNPs in cell culture. There was no significant difference between viability of HEK293 cells exposed to $0.78,1.56,3.125,6.25,12.5$ and $25 \mu \mathrm{g} / \mathrm{ml}$ of AgNPs. However, HEK293 cells viability remarkably decreased in groups exposed to 50 and $100 \mu \mathrm{g} / \mathrm{ml}$ of AgNPs compared to control cells $(P<0.05$ and $P<0.01$, respectively). The reduction in A549 cells viability was observed when exposed to 3.125 and $6.25 \mu \mathrm{g} / \mathrm{ml}$ of $\operatorname{AgNPs}(P<0.05$ and $P<0.01$, respectively). There was also statistically significant difference between viability of $A 549$ cells exposed to $12.5,25,50$ and $100 \mu \mathrm{g} / \mathrm{ml}$ of biosynthesized AgNPs $(P<0.001)$. For $A 549$ and HEK293 cell lines the IC50 values by cultivation in the presence of silver nanoparticles were calculated 9.87 and $111.26 \mu \mathrm{g} / \mathrm{ml}$, respectively. 
Figure 5B and 5D also shows viability of A549 and HEK293 cells exposed to 3.125, 6.25, 12.5, 25, 50 and $100 \mu \mathrm{g} / \mathrm{ml}$ of cisplatin in cell culture. A549 cells viability significantly declined in groups exposed to 50 and $100 \mu \mathrm{g} / \mathrm{ml}$ of cisplatin compared to control cells $(P<0.001)$. Exposure of A549 cells to $6.25(P<$ 0.05), 12.5 and $25(P<0.01) \mu \mathrm{g} / \mathrm{ml}$ of cisplatin also led to significant decrease in viability of A549 cells. However, there was no significant difference between viability of A549 cells exposed to $3.125 \mu \mathrm{g} / \mathrm{ml}$ of cisplatin compared to control cells. HEK293 Cell viability decreased greatly after exposure to 12.5 (P< 0.05), 25, $50(P<0.01)$ and $100(P<0.001) \mu \mathrm{g} / \mathrm{ml}$ of cisplatin. However, no significant differences were observed in the HEK293 cells viability at low doses (3.125 and $6.25 \mu \mathrm{g} / \mathrm{ml}$ ) of cisplatin. The IC50 values of cisplatin determined for A549 and HEK293 cell lines were 24.67 and $43.35 \mu \mathrm{g} / \mathrm{ml}$, respectively.

\section{Gene expression}

Figure 6 show the induction expression levels of caspase- 3 and caspase- 9 genes treated by AgNPs. According to Fig. 8a, the expression levels of caspase-3 and caspase-9 in cells exposed to synthetic AgNPs were higher than cisplatin treated cells. The results also revealed that AgNPs can down-regulation the expression levels of MMP2 and MMP9 in A549 cells which higher than cisplatin effect. Our result also was shown in Fig. 8c indicates the up-regulation of p53 and reduction of cyclin D1 in both AgNp and cisplatin treated A549 cells.

\section{Flow cytometric Apoptosis analysis}

To subsequent characterize apoptosis induction of AgNPs, A549 cells were stained with Annexin-V/PI assay, followed by flow cytometry test. The determination finding of flow cytometry assay was demonstrated in Fig. 10. The flow cytometry data obviously indicated that biosynthesized AgNPs can stimulate cell death procedure in A549 cells. Based on the Annexin V-FITC/PI staining, 96.1\% of control cells were detected viable with early apoptotic value of $0.84 \%$, late apoptotic value of $1.1 \%$, and necrotic value of $1.9 \%$ of cells, which are common process for cells can be proliferated in culture mediums. The A549 cells exposed to AgNPs dramatically induced the late apoptotic and necrotic cells as compared with untreated control cells. An increase in the percentage of apoptotic (early and late, Q2 + Q3) cells was detected with the value of 34.4 and $16.08 \%$ for ic50 of synthetic AgNPs and cisplatin, respectively. AgNPs significantly $(p<0.001)$ has lower necrotic effects (Annexin V -/PI+) $(4.0 \%, Q 1)$ in A549 cells at ic50 concentrations than cisplatin (Annexin V -/PI+) $(13.4 \%, \mathrm{Q})$, indicative of apoptotic cell death and side effects of cisplatin drug (Fig. 7).

\section{Cell cycle analysis}

To indicate the distribution of Juniperus polycarpos leaf extract AgNps and cisplatin-treated A549 cells in different phases of the cell cycle, the DNA content in cells was detected by PI staining and analyzed by flowcytometry. The results indicated that the treatment with both AgNPs and cisplatin led to an increase in the population of cells in the G0/G1 phase (Fig. 8). The results showed that $15.58 \%$ and $7.58 \%$ of the cells treated with nanoparticles and cisplatin respectively were recorded in the sub-G1 phase.

\section{Inhibition of migration and invasion of A549 cells}




\section{Scratch wound healing assay}

To examine the anti-metastatic properties of each drug, a scratch wound assay was performed in all three cell lines. A wound healing assay was performed to exclude the growth inhibitory effect of AgNPs and cisplatin on migration. The effect of AgNPs and cisplatin on A549 cells was detected, and it was identified that both AgNPs and cisplatin have great effects on cells migration. The results of the wound healing assays are presented in Fig. 9. The area that the cells had migrated (toward the initially scratched midline, from the border line) was measured. The cells incubated with AgNPs migrated across an area that was less than that of the cells incubated with the cisplatin and control medium, indicating that both AgNPs and cisplatin weaked the migration of the A549 cells.

Figure 9A Indicates the migration rate in control cells, B, shows the migration rate in A549 cells were treated with AgNPs and C, revealed the migration rate A549 cells were treated with cisplatin for $24 \mathrm{~h}$. Migration ability was determined by the migration rate of migrating cells at $24 \mathrm{~h}$.

\section{Invasion assay}

We accessed the effects of both AgNPs and cisplatin on invasion ability of A549 cells. As shown in Figs. 13, both AgNPs and cisplatin inhibited the migration dramatically compared with the control group. AgNPs and cisplatin decreased the migration ability from $85-30 \%$ and from $85-50 \%$, respectively (Fig. 10).

\section{Induction activation of caspases and ROS}

Caspases are the cysteine-aspartate proteases that play an important role in apoptosis. Caspase- 3 is the initiator caspase and caspase-9 is the executor caspase. The executor caspase expression level was increased in A549 lung cancer cell lines treated with both AgNPs and cisplatin but the caspase-3 expression level had significant increased only in cells treated with AgNPs (Fig. 11A). The intracellular ROS content of control, cisplatin and AgNPs treated A549 cells is depicted in Fig. 11B. Forty percent and 90\% increase in ROS content were observed in cisplatin and AgNPs-treated cells, respectively.

\section{Determination of Apoptotic Effects in A-549 Cells}

Apoptotic pathway or programmed cell death includes several changes in cells which contains morphology of cells, chromatin condensation, DNA, and nuclear fragmentation [35, 37]. In order to comparison the effect of AgNPs and cisplatin on cell death in A549 cells, nuclei of the cells were stain by DAPI stain. As shown in Fig. 12, higher levels of nuclear fragmentation, disintegration and condensation of chromatin at the boundary of the nuclear membrane and cell death were seen in AgNPs treated cells, compared to cells treated with cisplatin[19].

\section{Discussion}

Cancer is a leading cause of death worldwide, accounting for an estimated 9.6 million deaths in 2018[20]. Lung cancer is the most universally occurring cancer in men and the third most commonly occurring 
cancer in women, contributing about $11.6 \%$ of the total cancer incidence burden[20]. Natural compounds propose benefits over synthetic drugs, including low side effects, so medicinal herbs have long captured the attention of researchers[21]. In the current investigation, the anticancer effects of green-synthesize AgNPs using Juniperus polycarpos on A549 (adenocarcinomic human alveolar basal epithelial cells) cell lines was assayed. Additionally, the expression of apoptotic and metastatic genes including caspase-3, caspase-9, MMP2 and MMP9 was evaluated.

According to results, AgNPs have been efficiently synthesized using Juniperus polycarpos extract, which SEM, TEM, XRD, UV-vis, EDS and FTIR methodes confirmed the changes in the chemical composition, morphology and size of the Ag nanoparticles. Juniperus polycarpos is economically cheap and easily available and AgNPs are obtained from nature can act as both reducing and capping agent. Recently, recent studies indicated that herbal extracts have been applied for the green synthesis of AgNPs[22]. The specific mechanism of silver nanoparticles bioreduction is not fully understood yet but various investigations suggested the mechanism of metallic nanoparticle synthesis using plant extracts. There exist several biomolecules in plants which are engaged in reduction and biosynthesis of metal nanoparticles[23].

MTT assay was carried out to survey the in vitro cytotoxic trait of biosynthetic AgNPs and cisplatin drug. A549 cells were treated with different concentration of synthesised AgNPs and cisplatin for $24 \mathrm{~h}$ to establish the inhibitory percentage against cancer treated and untreated cell lines. Our study findings showed that the cancer and normal cells viability were clearly proportionate to the concentration of the AgNPs. When the IC50 of the AgNPs and cisplatin was compared, the synthesised AgNPs showed lower percentage of inhibition of cells proliferation at lower concentration against the A549 cancer cells than the cisplatin. At lower concentrations the AgNPs demonstrate remarkable toxicity on the growth of A549 cells but the cell viability did not reduce significantly with lower concentrations of drug. The results of the MTT assays also showed that AgNPs exhibited the lower cytotoxicity against HEK293 cells than cisplatin, which indicated that exposure to the cisplatin was associated with increased cell death and cisplatin-DNA intra-strand crosslinks result in cytotoxicity due to the presence of the platinum in its structure[24]. The analysis demonstrated that the anticancer activity of synthesized AgNPs mainly show a dose-response relationship and cytotoxicity increased at higher concentrations. Among the nanoparticles, AgNPs were found to be best for inhibition of cancer cell proliferation[25]. It might be due to the synergetic properties of bio-molecular groups derived from Juniperus polycarpos that held in nanoparticles formation procedure. This is the first comparative investigation to introduce the cytotoxicity of phyto-synthesised AgNPs using Juniperus polycarpos extract and cisplatin drug against A549 cells. We believed that phyto-synthesis of AgNPs could lead ultimately to apoptotic cell death, DNA damage and the cell morphology alterations[26].

Considering the importance role of these genes in apoptotic and necrotic pathway, the Real-time PCR results indicate that caspase3- and caspase-9 genes expression levels were induced with both exposure to Ic50 of synthetic AgNPs and cisplatin. AgNPs also is more powerful to decrease expression of MMP2 and MMP9 genes than commercial drug. Various in vitro reports indicates that biogenic AgNPs decreased 
the mRNA and protein expression of MMP-2 and MMP-9 in wounded granulation tissues[27]. A huge amount of studies show treating MCF-7 cancer cells with AgNPs induces apoptosis by inducing the release of cytochrome c, production of reactive oxygen species [1], and activation of the caspase-3 pathway[28].

Further investigation included the annexin V/PI assay, followed by flow cytometry. In the early apoptosis stage, alterations take place at the cell surface and phosphatidylserins (PS) in the membrane is translocated from the inner to the outer leaflet of the plasma of cell membrane. Annexin- $\mathrm{V}$ with PI staining could be used for detection of PS exposing cells via flow-cytometry method. The groups of cells resident in the Annexin V+/PI- and the Annexin V+/PI + were identified as the early and late stage of apoptosis, respectively. [29]. The staining results showed The A549 cells exposed to AgNPs significantly increased the early and late apoptotic and necrotic cells as compared with untreated control cells. In contrast, the early, late apoptotic cell percentages cells treated with AgNPs were found to be higher than cisplatin treatments, while the percentages of necrotic cell (Annexin V-/PI+) was lower than the treatment with cisplatin. This results indicated that AgNPs is more effective in apoptosis and has lower necrotic effects on cells than cisplatin drug.

The anticancer action of silver nanoparticles is due to wide spectrum of biological activities in cancer cells cycle proliferation, which resulted in deprived of cancer cells ability for division and growth[30]. Our data suggest that the treatment of A549 cells with biosynthesized AgNPs resulted in considerable sub-G1 phase deterrence of cell cycle proliferation, showing one of the mechanisms by which the AgNPs may act to suppress cancer cell viability and tumor growth. The reduction in cells population treated with the AgNPs and cisplatin was observed in $\mathrm{G} 2$ and $\mathrm{S}$ phase, whereas the cell population in the sub- G1 phase was enhanced when compared with controls. These data imply that both biosynthesized AgNPs and cisplatin progressed cell cycle development in the sub G1 phase arrest.

Since tumor cell migration and invasion is required for cancer metastasis, wound healing, scratch, and invasion assays were conducted to assess the progression of cancer cell development in A549 cell lines, following treatment with AgNPs and cisplatin, which the results were shown all cell lines treated with AgNPs and cisplatin invaded and migrated, but the antimigratory effect of AgNPs in A549 cells was significantly higher than cisplatin treated cells and control. These results proved that our targeted drugloaded nanoparticle can be used effectively in lung cancer cell lines.

Various NP particularly AgNPs can stimulate oxidative stress through ROS generation, which may induce apoptotic pathway in reaction to different signals and pathophysiological conditions[31, 32]. Several studies have indicated the roles of numerous metal NPs including AgNPs in induction of ROS generation in many cell lines [32,33]. AgNPs have been considered as one of the most potent candidates in medical application of nanotechnology via ROS production[34]. In this assay, we have reported that significant increase in ROS content were observed in cisplatin and AgNPs-treated cells, respectively, which indicates the initiation of apoptosis by the biosynthesized AgNP. 
The current study indicate Up-regulation of p53 in A549 cells under treatment of AgNp that can arrest cells in a sub-G1 phase cell cycle and prepare cells for induction apoptosis. Down-regulation of cyclin D1 stop cells at the G0/G1 phase and prevents cell progression to next phases and by increasing capase 3/9 evokes apoptosis in arrested cells [35-37].

\section{Conclusion}

This is the earliest investigation to develop economical, simple, and eco-friendly procedure for biosynthesis of silver nanoparticles using Juniperus polycarpos extract as reducing agent. AgNPs were synthesized and characterized using UV-vis spectroscopic, XRD analysis, SEM, EDS, TEM and FT-IR; these process evidenced the presence of AgNPs with an average size of $38.8 \mathrm{~nm}$. The bioprepared AgNPs demonstrated greater favorable anticancer potential than cisplatin drug and can be utilized in pharmaceutical industries. The AgNPs were demonstrated as considerable apoptosis inducing and metastatic reducing agents against cancer cell lines. The phyto-synthesised AgNPs have potent cytotoxic activity against A549 cell line compared with cisplatin drug. Moreover, the Annexin V/PI staining, cell cycle analysis, wound healing assay, cell migration and invasion assay, production of caspases and ROS strains results indicated the AgNPs-induced cytotoxicity reduced A549 cells viability, which is referred to capability of AgNPs to stimulate apoptosis pathway rather than necrosis. Therefore, subsequent investigations are required to quietly clarify the mechanism of action of silver nanoparticles toxicity against cancer cell lines.

\section{Declarations}

\section{Acknowledgements}

The authors would like to acknowledge the laboratory of Islamic Azad University.

\section{Disclosure statement}

The authors declare that they have no conflict of interest.

\section{References}

1. A. M. Iniyan, R. R. Kannan, F.-J. R. S. Joseph, T. R. J. Mary, M. Rajasekar, P. C. Sumy, A. M. Rabel, D. Ramachandran and S. G. P. Vincent (2017) Microbial pathogenesis 112:76-82

2. M. Singh and T. Sahareen (2017) LWT 86:116-122

3. L. C. Yun'an Qing, R. Li, G. Liu, Y. Zhang, X. Tang, J. Wang, H. Liu and Y. Qin (2018) International journal of nanomedicine 13:3311

4. M. P. Patil and G.-D. Kim (2017) Applied microbiology and biotechnology 101:79-92 
5. V. Kumar and S. K. Yadav (2009) Journal of Chemical Technology \& Biotechnology: International Research in Process, Environmental \& Clean Technology 84:151-157

6. K. Gopinath, S. Kumaraguru, K. Bhakyaraj, S. Mohan, K. S. Venkatesh, M. Esakkirajan, P. Kaleeswarran, N. S. Alharbi, S. Kadaikunnan and M. Govindarajan (2016) Microbial pathogenesis 101:1-11

7. A.-C. Burdușel, O. Gherasim, A. M. Grumezescu, L. Mogoantă, A. Ficai and E. Andronescu (2018) Nanomaterials 8:681

8. F. Ghanbar, A. Mirzaie, F. Ashrafi, H. Noorbazargan, M. D. Jalali, S. Salehi and S. A. S. Shandiz (2016) IET nanobiotechnology 11:485-492

9. K. Venugopal, H. Rather, K. Rajagopal, M. Shanthi, K. Sheriff, M. Illiyas, R. Rather, E. Manikandan, S. Uvarajan and M. Bhaskar (2017) Journal of Photochemistry and Photobiology B: Biology 167:282289

10. E. S. Al-Sheddi, N. N. Farshori, M. M. Al-Oqail, S. M. Al-Massarani, Q. Saquib, R. Wahab, J. Musarrat, A. A. Al-Khedhairy and M. A. Siddiqui (2018) Bioinorganic Chemistry and Applications 2018

11. Y. He, Z. Du, S. Ma, Y. Liu, D. Li, H. Huang, S. Jiang, S. Cheng, W. Wu and K. Zhang (2016) International journal of nanomedicine 11:1879

12. M. Annu, S. Ahmed, G. Kaur, P. Sharma, S. Singh and S. Ikram (2018) Toxicology research 7:923-930

13. K. Al-Dhafri and C. L. Ching (2019) Biocatalysis and agricultural biotechnology 18:101075

14. L. Galluzzi, L. Senovilla, I. Vitale, J. Michels, I. Martins, O. Kepp, M. Castedo and G. Kroemer (2012) Oncogene 31:1869-1883

15. H. Zhu, H. Luo, W. Zhang, Z. Shen, X. Hu and X. Zhu (2016) Drug design, development and therapy 10:1885

16. S. Mukherjee, D. Chowdhury, R. Kotcherlakota and S. Patra (2014) Theranostics 4:316

17. R. Vivek, R. Thangam, K. Muthuchelian, P. Gunasekaran, K. Kaveri and S. Kannan (2012) Process Biochemistry 47:2405-2410

18. S. Honary and F. Zahir (2013) Tropical Journal of Pharmaceutical Research 12:255-264

19. S. S. Azandeh, M. Abbaspour, A. Khodadadi, L. Khorsandi, M. Orazizadeh and A. Heidari-Moghadam (2017) Iranian journal of pharmaceutical research: IJPR 16:868

20. F. Bray, J. Ferlay, I. Soerjomataram, R. L. Siegel, L. A. Torre and A. Jemal (2018) CA: a cancer journal for clinicians 68:394-424

21. N. E. Thomford, D. A. Senthebane, A. Rowe, D. Munro, P. Seele, A. Maroyi and K. Dzobo (2018) International journal of molecular sciences 19:1578

22. S. K. Srikar, D. D. Giri, D. B. Pal, P. K. Mishra and S. N. Upadhyay (2016) Green and Sustainable Chemistry 6:34

23. S. Iravani, H. Korbekandi, S. V. Mirmohammadi and H. Mekanik (2014) Reviews in Advanced Sciences and Engineering 3:261-274

24. S. Manohar and N. Leung (2018) Journal of nephrology 31:15-25 
25. S. Ghozali, L. Vuanghao and N. Ahmad (2015) C roseus,

26. H. Khalili, S. A. S. Shandiz and F. Baghbani-Arani (2017) Journal of Cluster Science 28:1617-1636

27. N. Krishnan, B. Velramar, B. Ramatchandirin, G. C. Abraham, N. Duraisamy, R. Pandiyan and R. K. Velu (2018) Materials Science and Engineering: C 91:146-152

28. A. G. Al-Nuairi, K. A. Mosa, M. G. Mohammad, A. El-Keblawy, S. Soliman and H. Alawadhi (2019) Biological trace element research:1-10

29. Y. Pan, W. Shan, H. Fang, M. Guo, Z. Nie, Y. Huang and S. Yao (2014) Biosensors and Bioelectronics $52: 62-68$

30. G. Raja, Y.-K. Jang, J.-S. Suh, H.-S. Kim, S. H. Ahn and T.-J. Kim (2020) Cancers 12:664

31. A. Abdal Dayem, M. K. Hossain, S. B. Lee, K. Kim, S. K. Saha, G.-M. Yang, H. Y. Choi and S.-G. Cho (2017) International journal of molecular sciences 18:120

32. M. Nita and A. Grzybowski (2016) Oxidative Medicine and Cellular Longevity 2016

33. A. Avalos, A. I. Haza, D. Mateo and P. Morales (2014) Journal of applied toxicology 34:413-423

34. A. El-Hussein and M. R. Hamblin (2016) IET nanobiotechnology 11:173-178

35. M. Rahimivand, F. Tafvizi and H. NoorBazargan (2020) International Journal of Biological Macromolecules,

36. N. N. Fard, H. Noorbazargan, A. Mirzaie, M. Hedayati Ch, Z. Moghimiyan and A. Rahimi (2018) Artificial cells, nanomedicine, and biotechnology 46:S1047-S1058

37. S. Aslany, F. Tafvizi and V. Naseh (2020) Materials Today Communications 24:101011

\section{Figures}




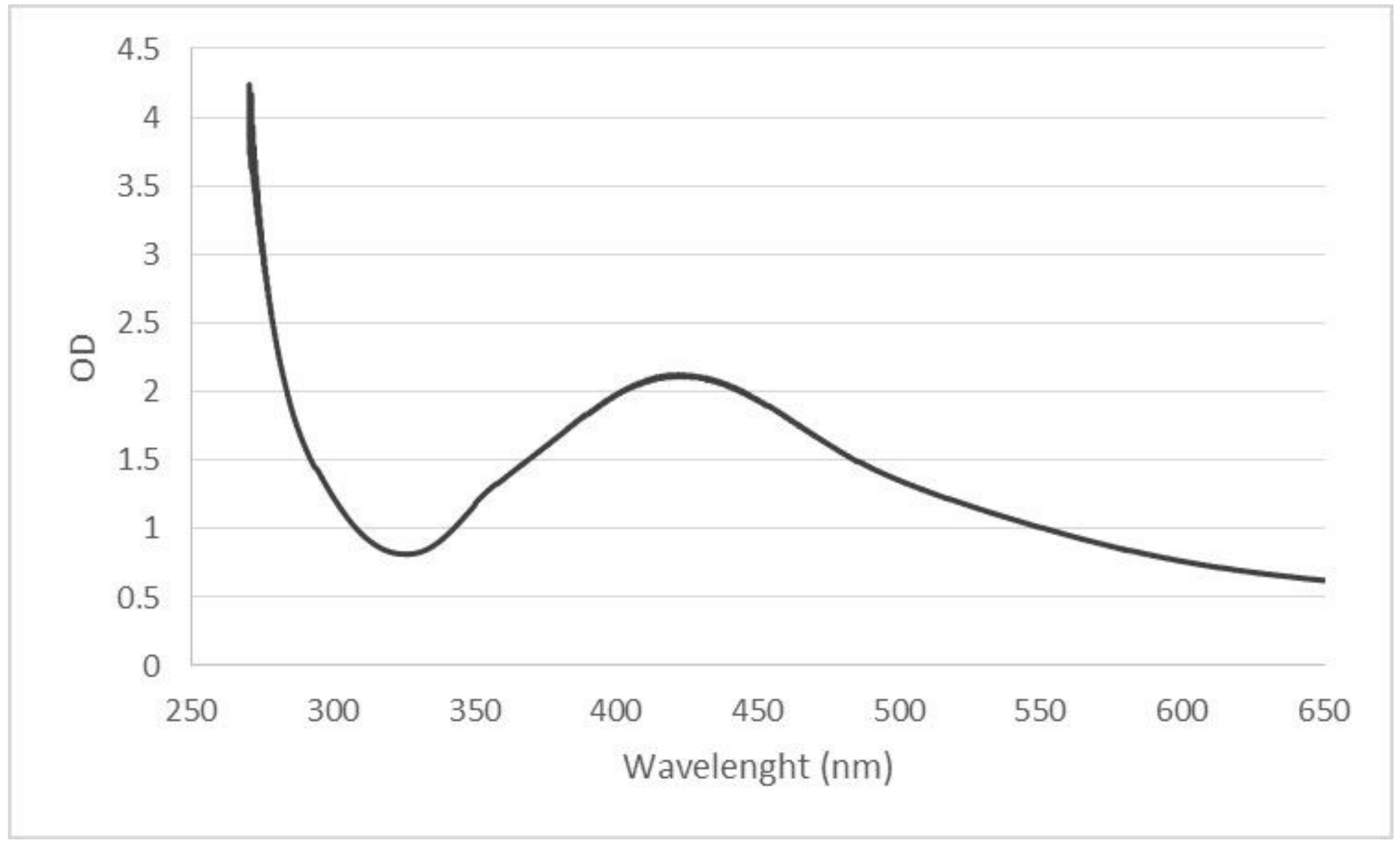

Figure 1

UV-visible spectrum of biologically synthesized silver nanoparticles during the reaction. 

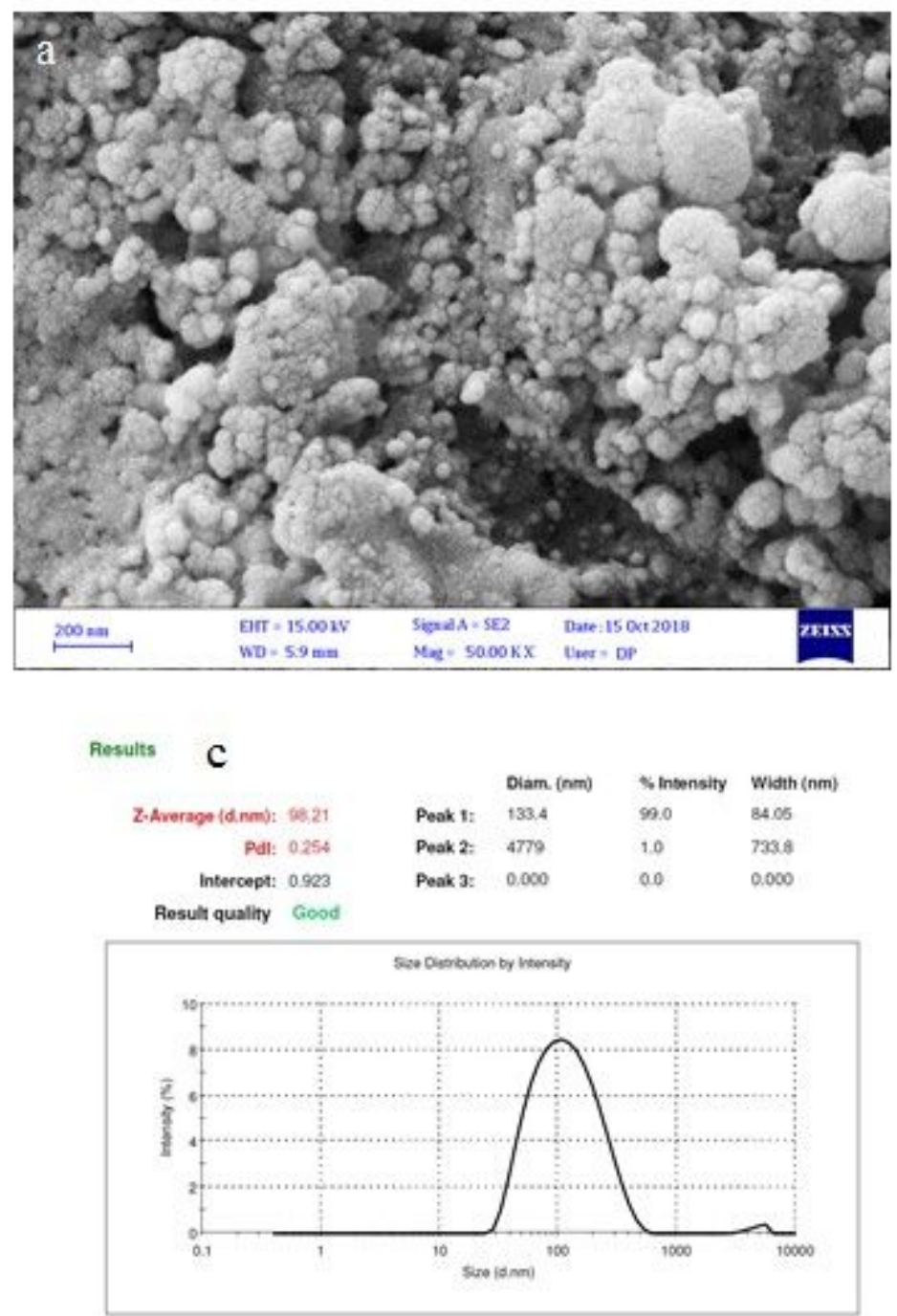

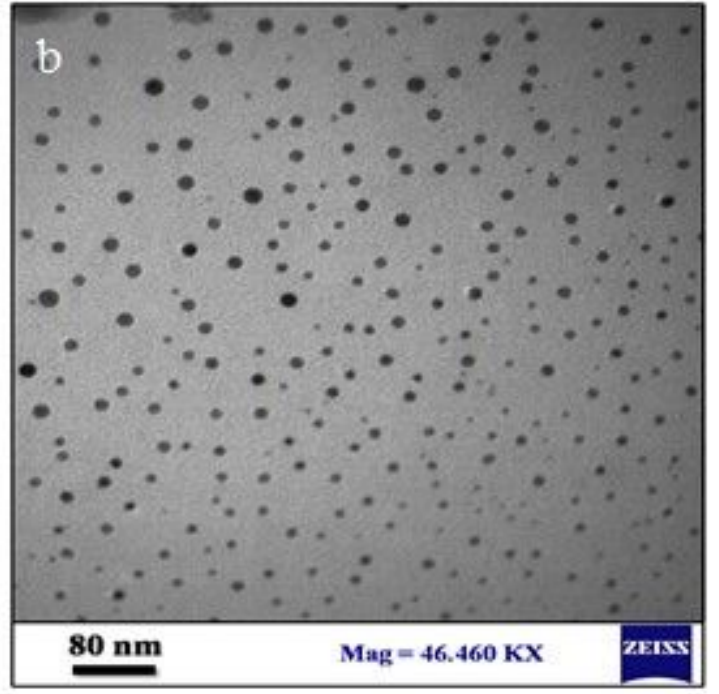

d

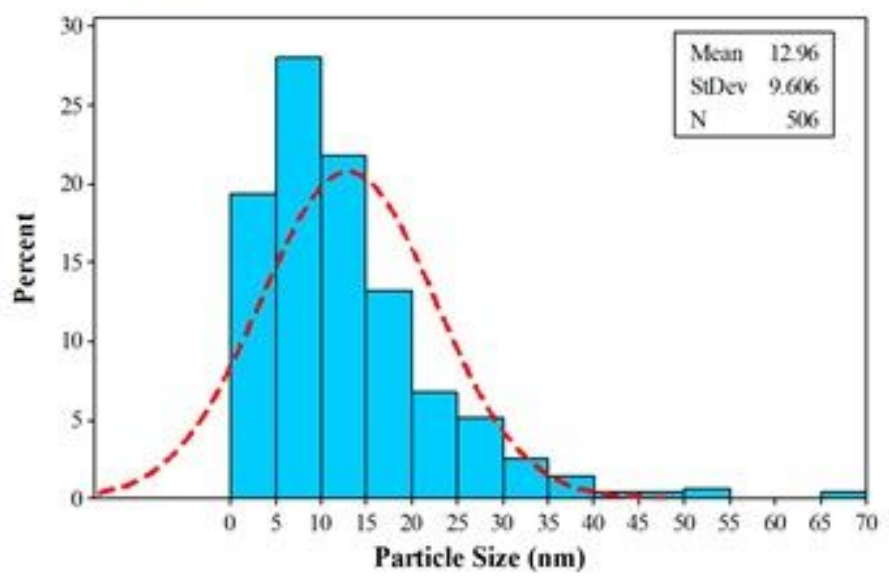

Figure 2

a) SEM analysis of AgNPs synthesized using green method in optimal conditions, b) TEM micrographs of synthesized AgNPs using green synthesis method, c) DLS analysis and d) histogram of particles size. 

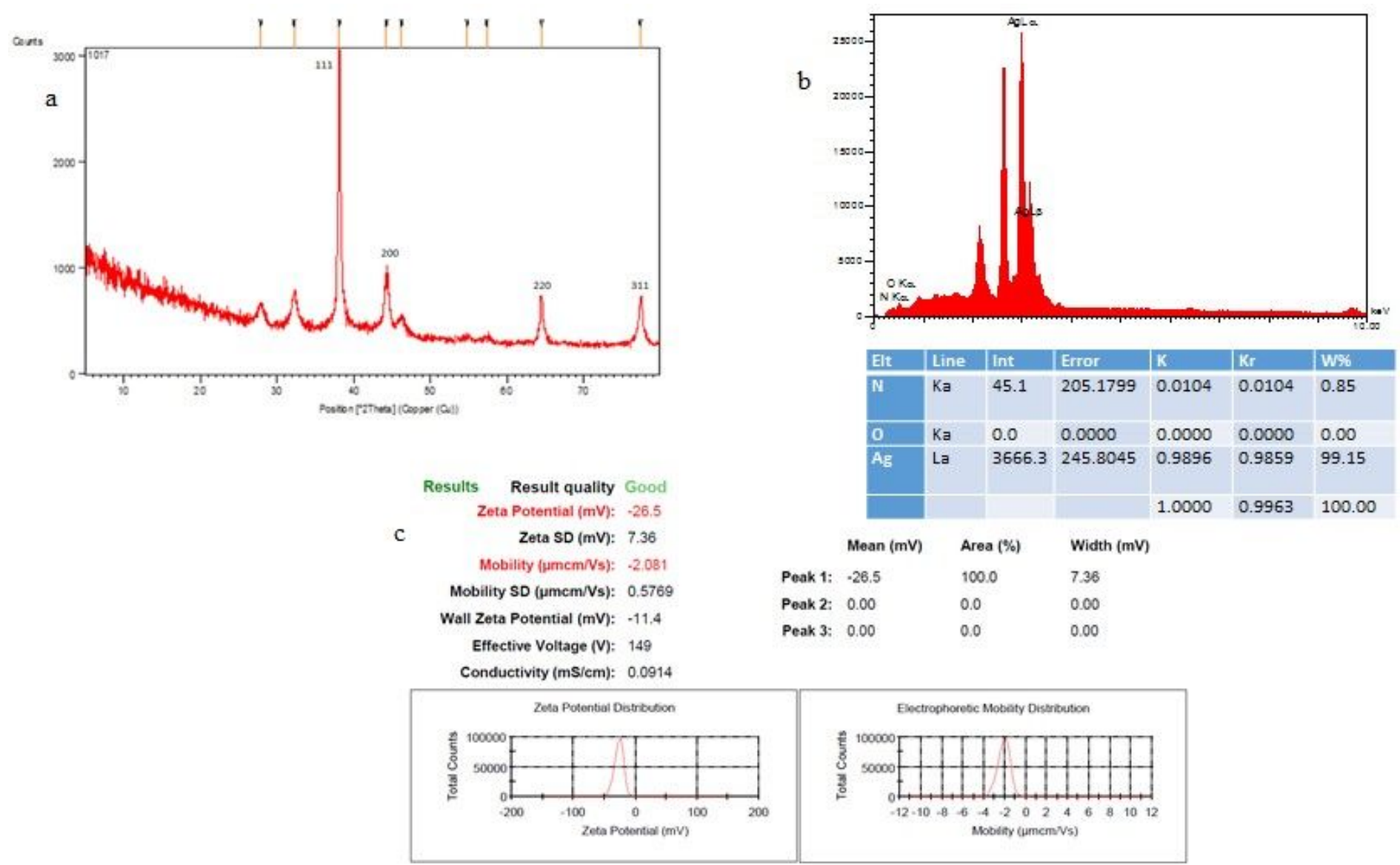

\section{Figure 3}

a) XRD pattern of AgNPs synthesized using Juniperus polycarpos extract. b) EDS spectrum of silver nanoparticles synthesized by Juniperus polycarpos. C) Zeta potential of synthesized AgNPs fabricated using aqueous leaf extract of Juniperus polycarpos. 


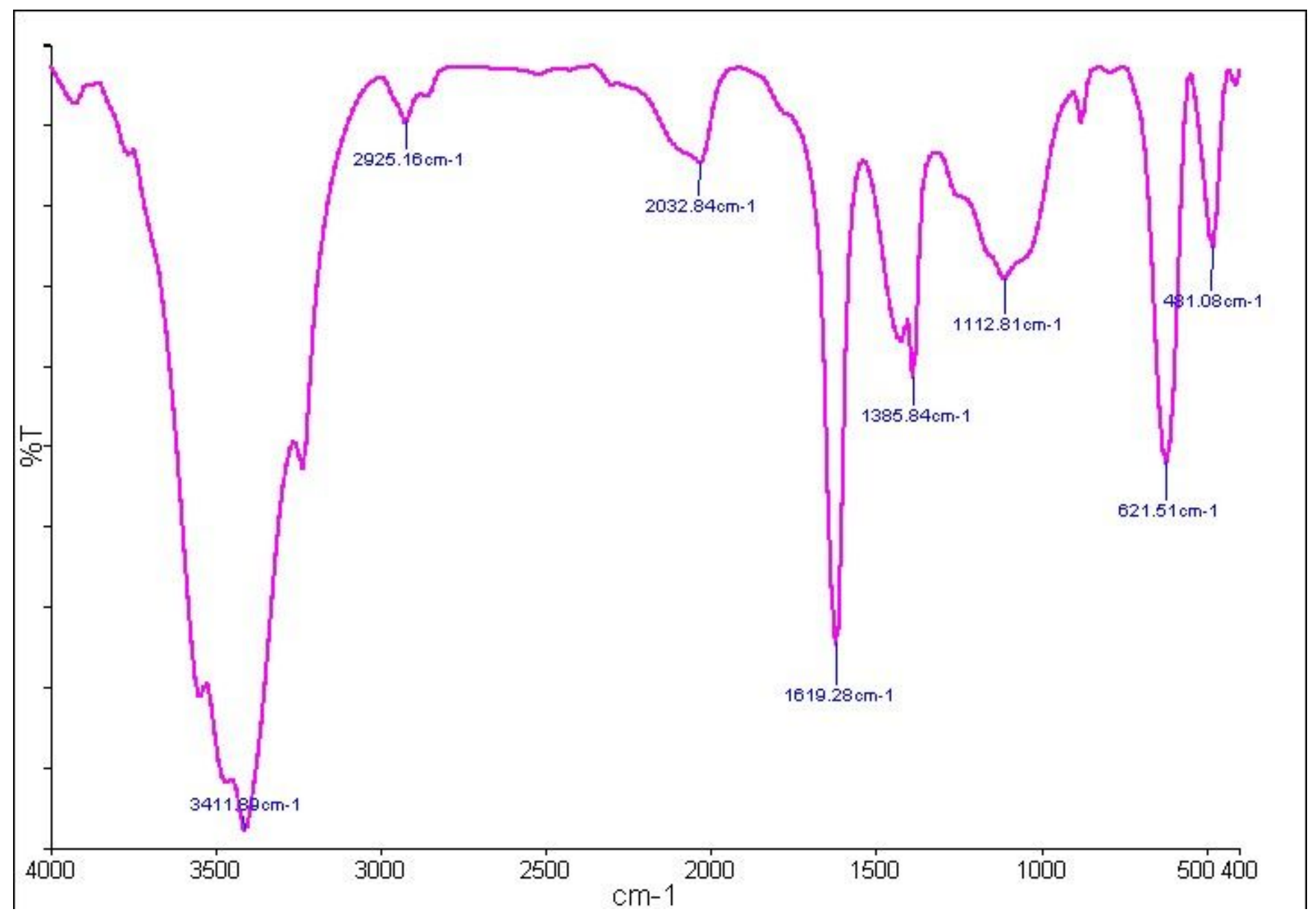

Figure 4

Indicates the FTIR spectrum of the synthesized AgNPs by Juniperus polycarpos extract. 


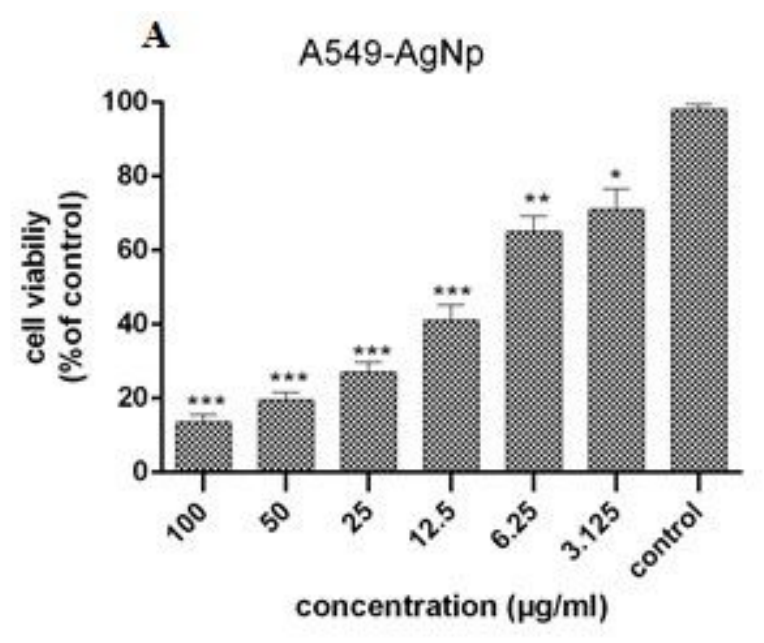

C

HEK293-AgNp

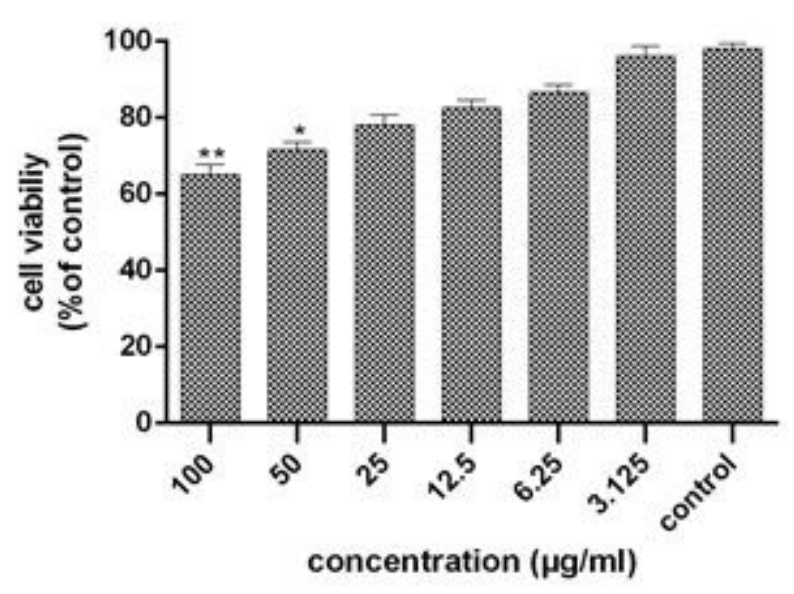

B

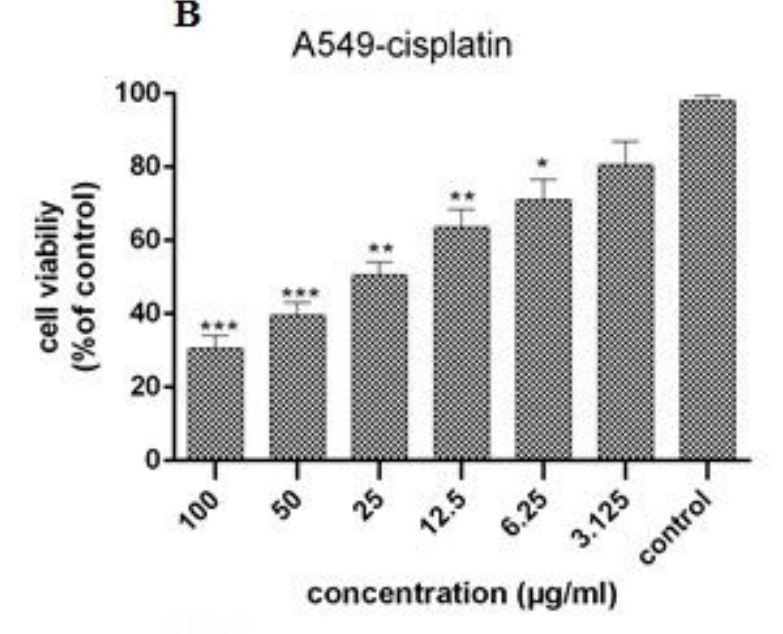

D

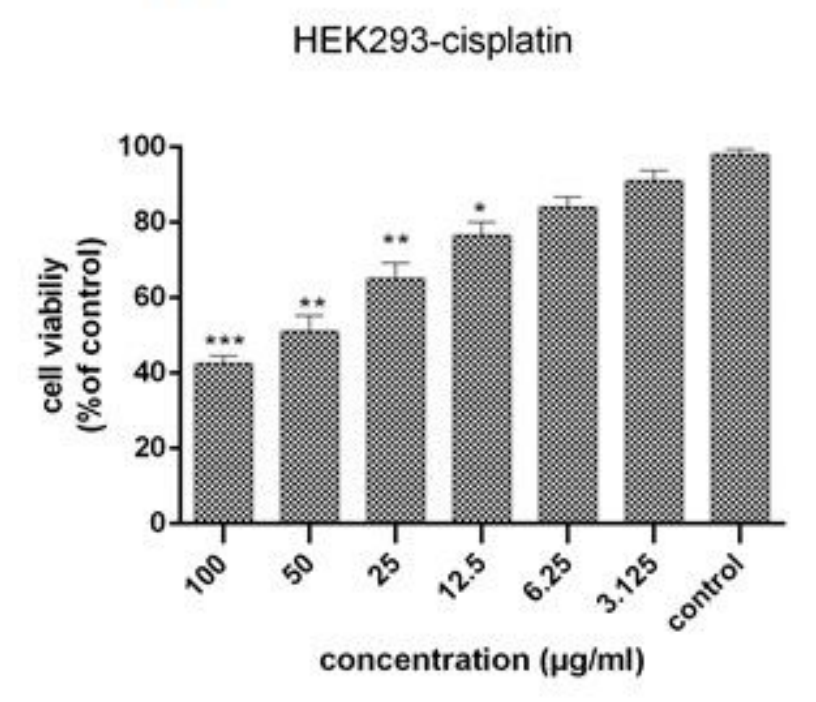

\section{Figure 5}

Viability of A549 and HEK293 Cells Exposed different concentration of bio-synthesized AgNPS and cisplatin in Cell Culture. * indicate significant difference compared with control. (***:P<0.001, ${ }^{\star *}: P<0.01$ and $* *: P<0.05)$. 


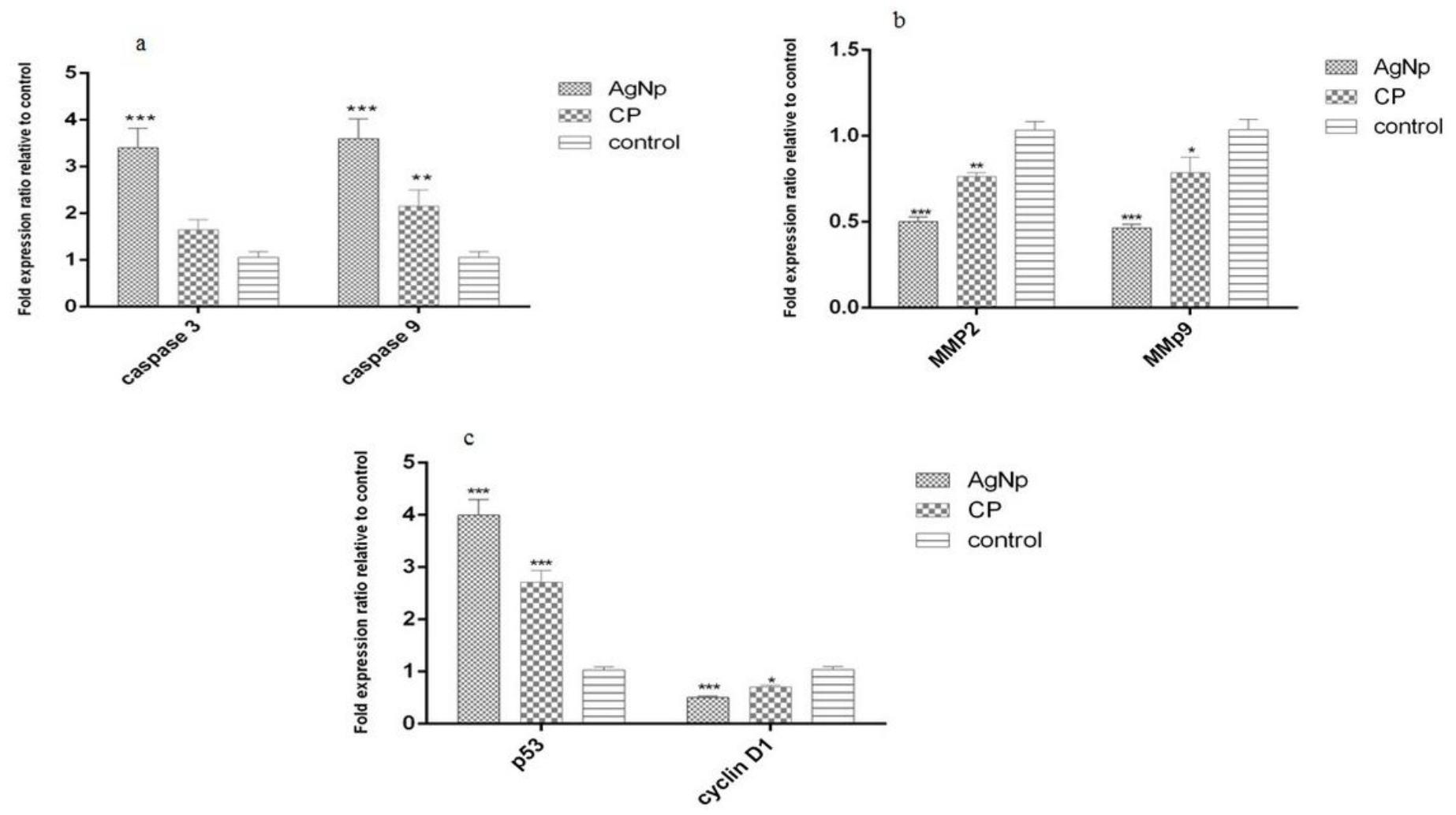

Figure 6

Expression levels of caspase-3, caspase-9, MMP2, MMP9 and p53 and cyclin D1 genes exposed to biosynthesize AgNPs and cisplatin. (***:P<0.001 and $* *: P<0.01)$. 

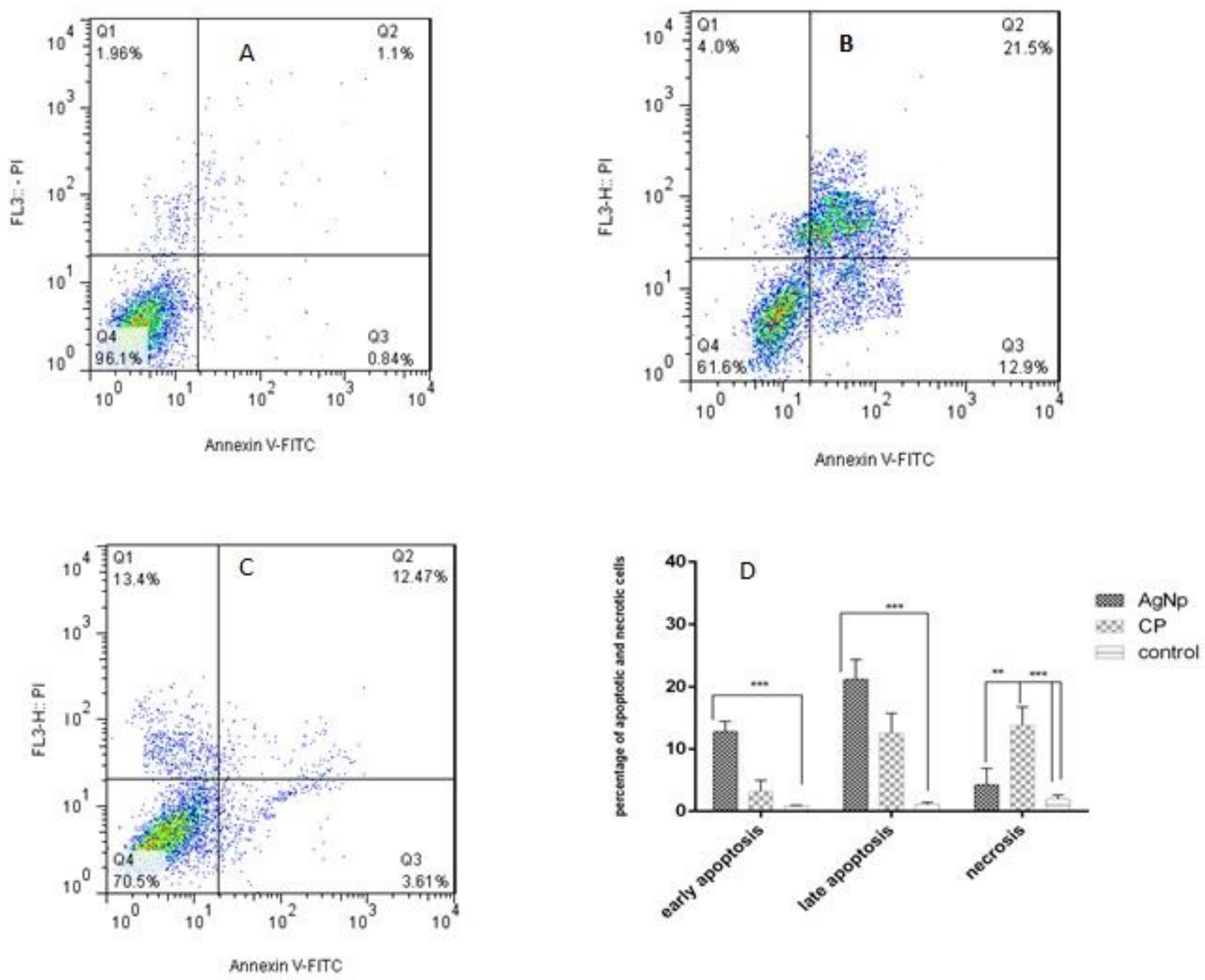

\section{Figure 7}

Flow cytometric analysis by Annexin V-FITC in the y-axis and PI (FL3) in the x-axis double staining of A549 cell line treated with green synthesised AgNPs and cisplatin after $24 \mathrm{~h}$ exposure. Dot plots of Annexin V/PI staining are shown in (a) Untreated A549 cells, (b) A549 cells treated with IC50 concentration of AgNPs. (c) A549 cells treated with IC50 concentration of cisplatin. 

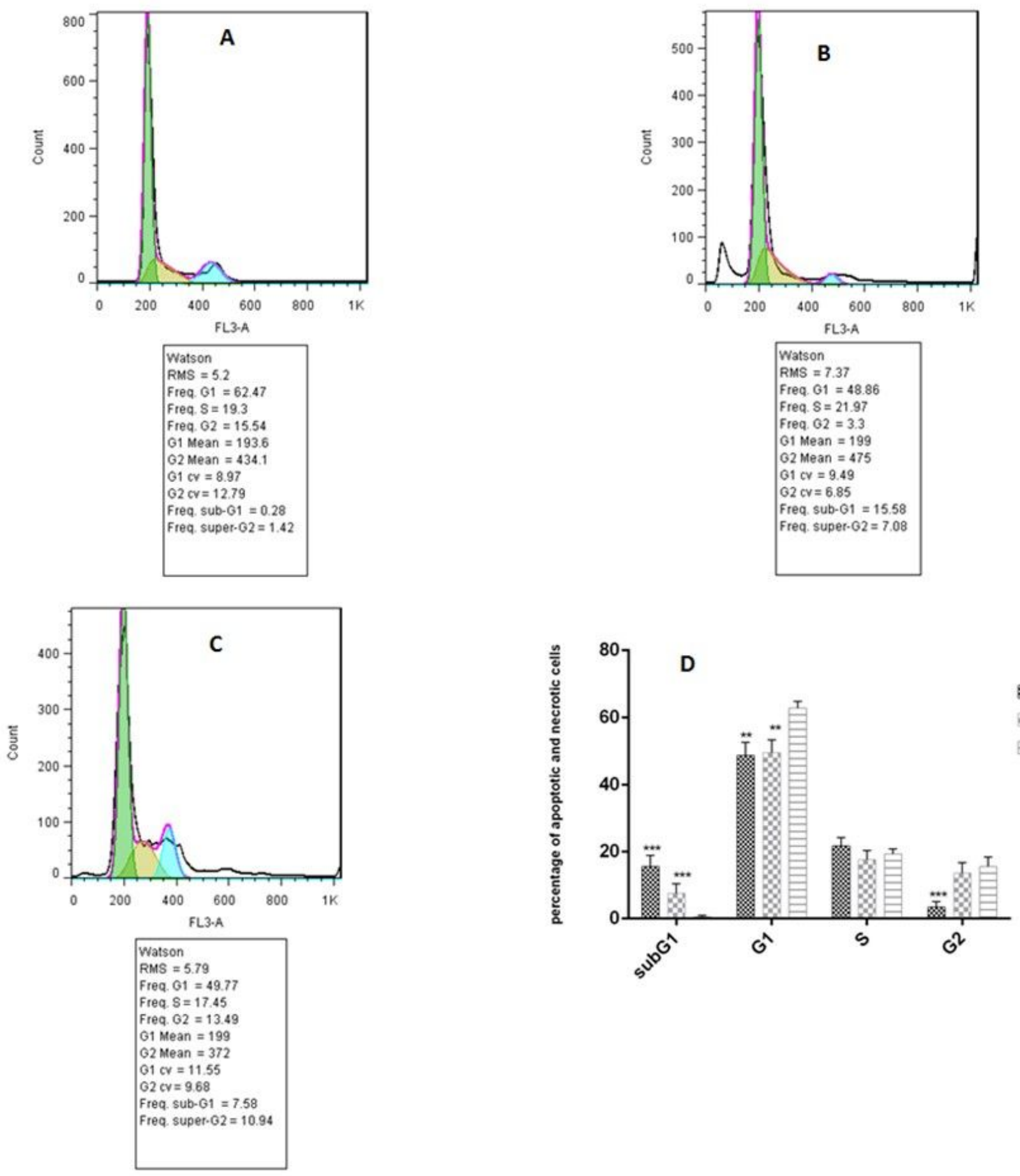

\section{Figure 8}

Cell cycle analysis using flow cytometry. (A) control cells, (B) AgNp treated cells, (C) cisplatin treated cells. The initial, middle, and last peaks represent subG1, G1, S and G2, respectively. (D) Bar chart depicting the percentage of resistant cells in subG1, G1, S and G2. (**p $<0.01$, and $\left.{ }^{\star \star *} p<0.001\right)$. 

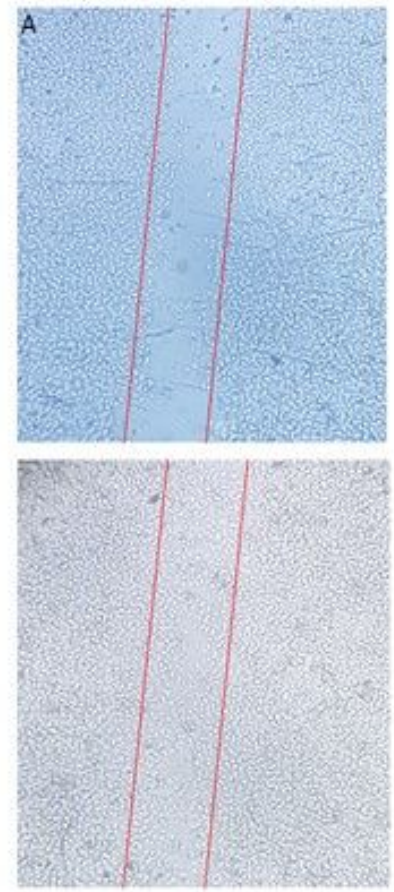
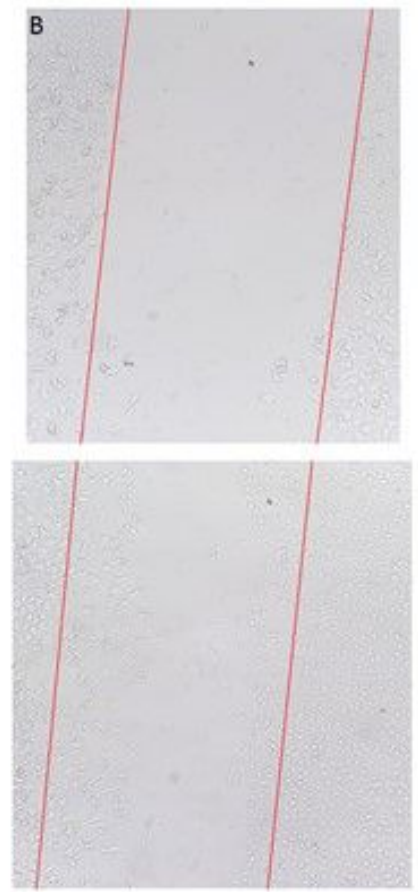
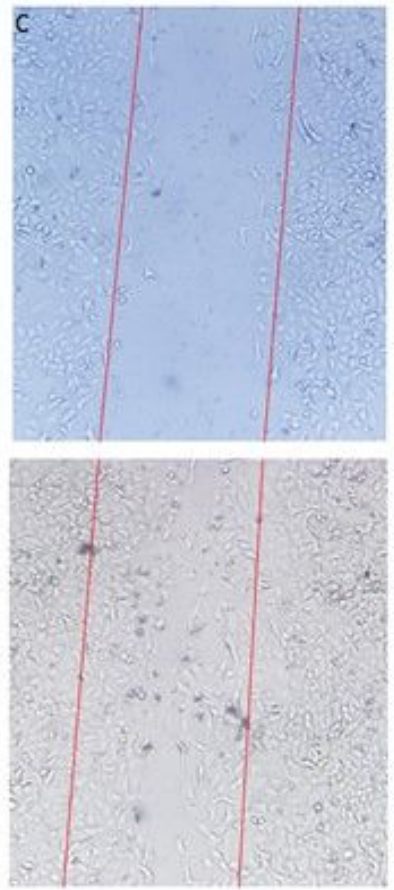

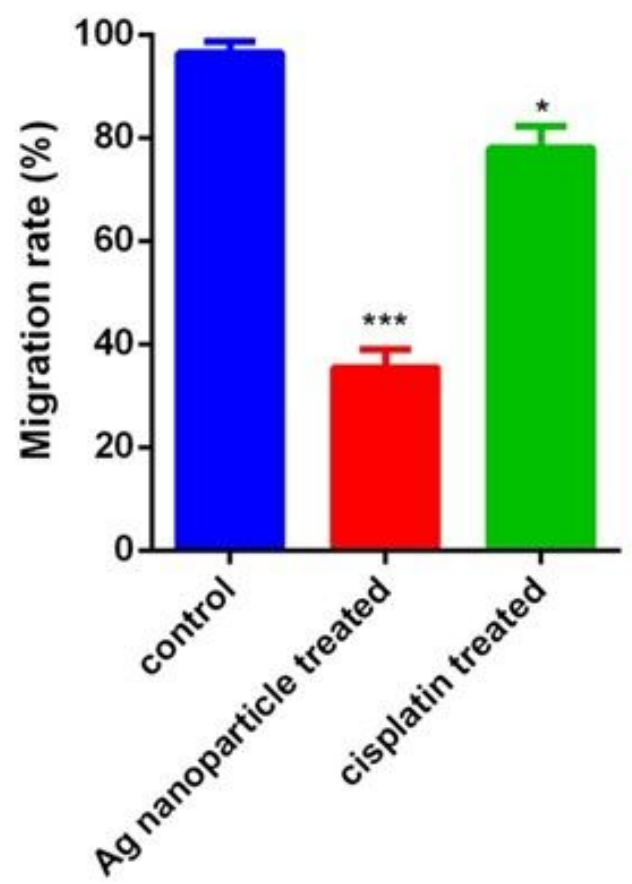

\section{Figure 9}

Inhibition of A549 lung cancer cell lines migration in an "in vitro wound-healing" assay. (A) untreated control cells, (B) treated cells with AgNPs and (C) treated cells with cisplatin for $24 \mathrm{~h}$. Bar chart depicting the number of migrated cells per field The results were obtained from triplicate experiments and are presented the mean \pm standard deviation $(n=3)$. $\left({ }^{\star} p<0.05\right.$, and $\left.{ }^{\star \star \star} p<0.00\right)$.
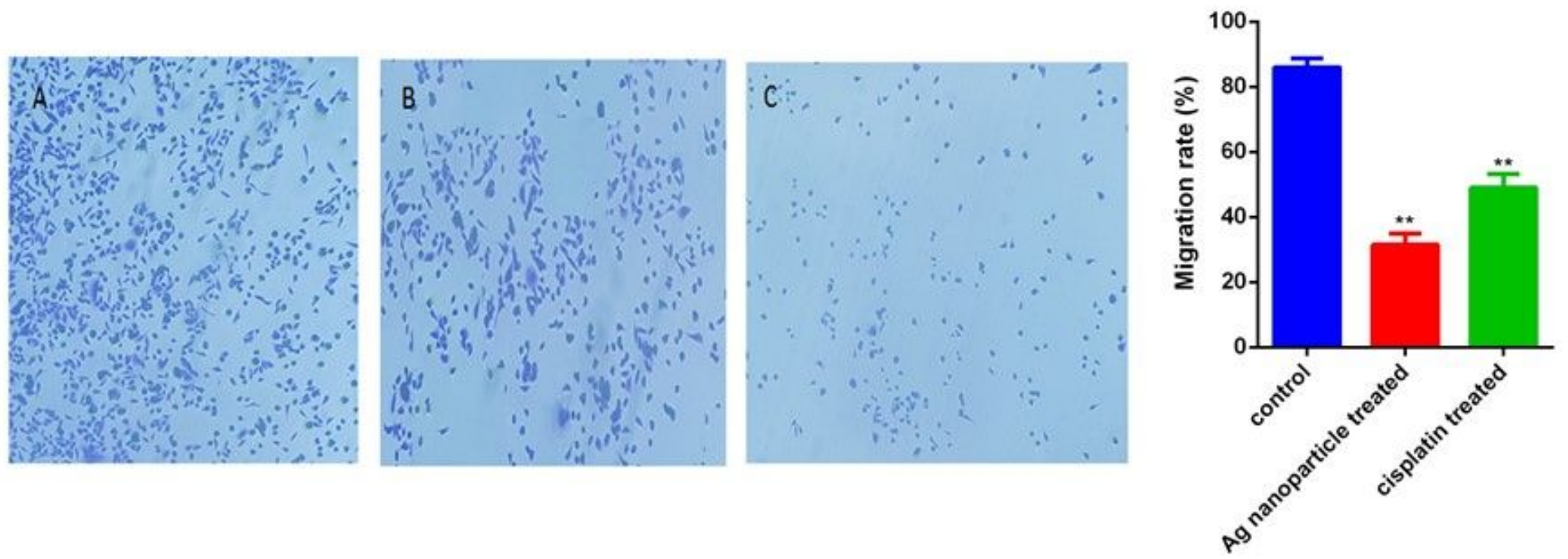

\section{Figure 10}

AgNPs and cisplatin reduces cell mobility. (A) Indicates the invasion rate in control cells, (B) and revealed the invasion rate $A 549$ cells were treated with cisplatin (C) shows the invasion rate in A549 cells were treated with AgNPs for $24 \mathrm{~h}$. The results were obtained from triplicate experiments and are presented the mean \pm standard deviation $(n=3)$. $* \star p<0.01$. 

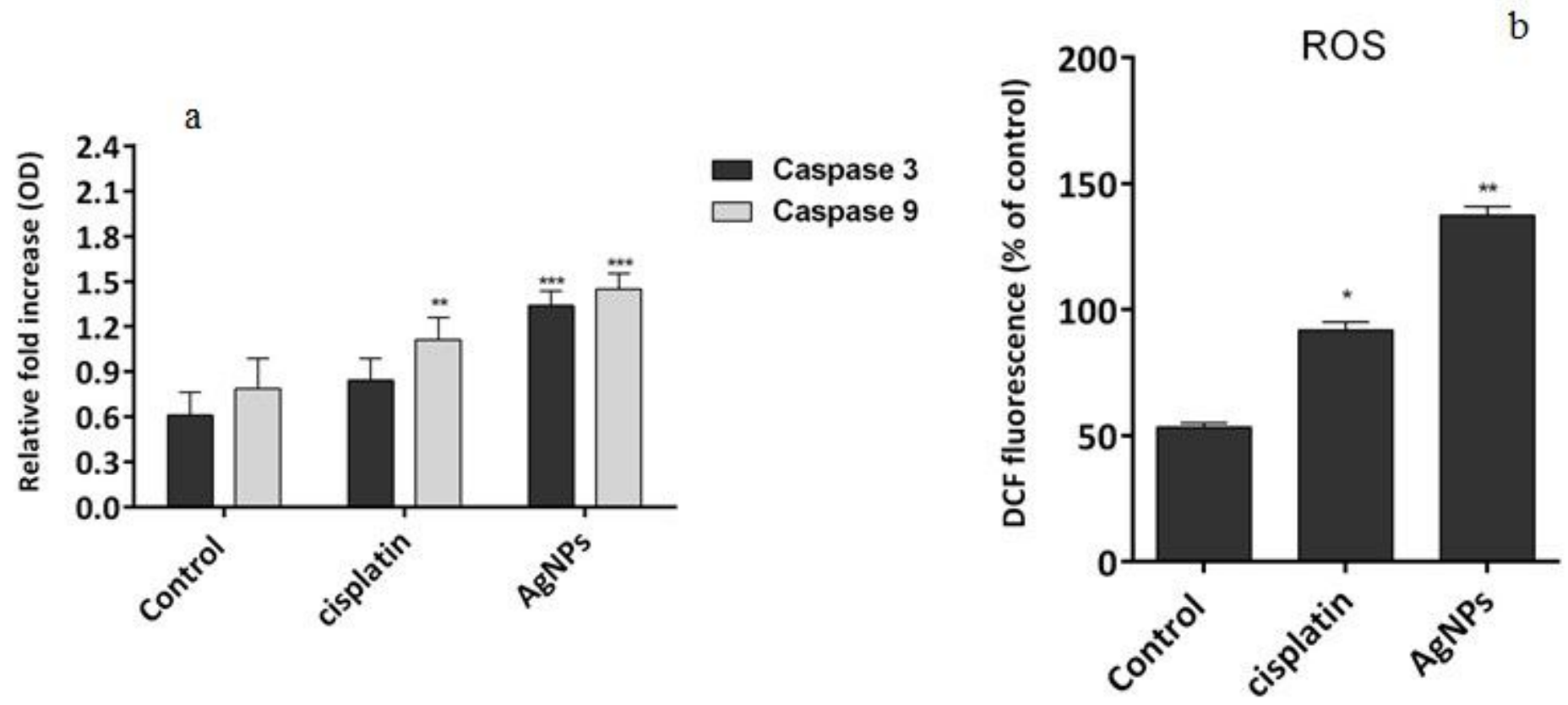

Figure 11

Effect of silver and cisplatin nanoparticles synthesized from Juniperus polycarpos on caspases (A) and ROS production (C) in A549 lung carcinoma cell line. Each bar represents mean \pm SEM of three independent observations. ${ }^{*} P<0.05$ and ${ }^{*} * \mathrm{P}<0.01$ are considered as statistically significant.
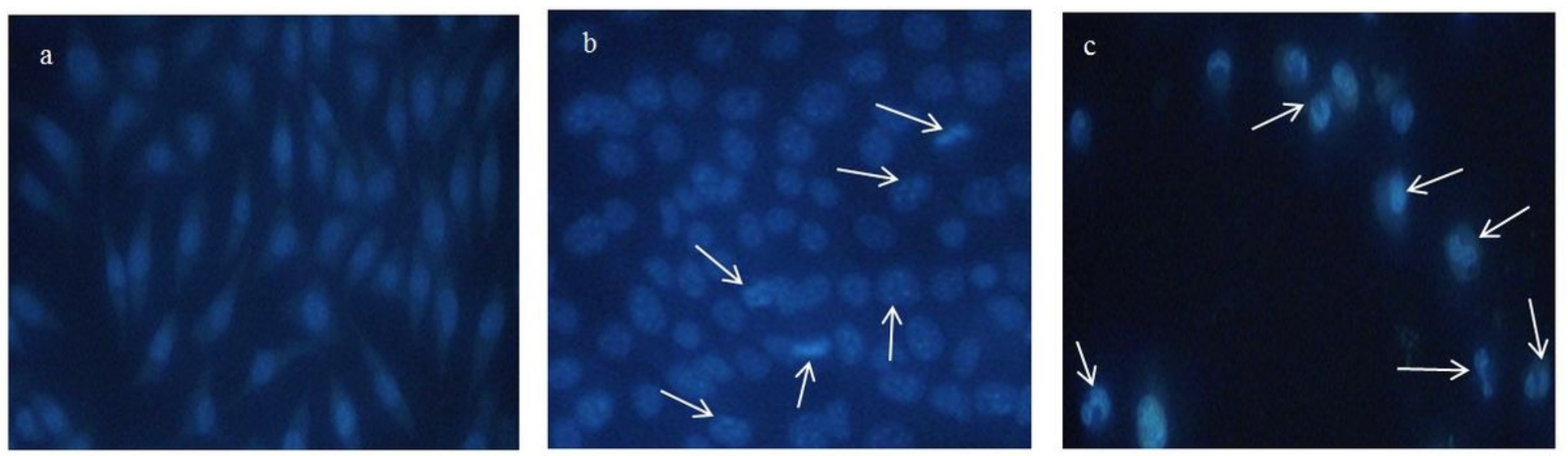

\section{Figure 12}

DAPI nuclear staining, a) represents control group, b) represents the group that treated with cisplatin, c) cell treated with cisplatin. 